\title{
Assessment of mercury contamination in the Bílina River (Czech Republic) using indicator fish
}

\author{
Kamila Kružíková, Zdeňka Svobodová \\ Department of Veterinary Public Health and Toxicology, Faculty of Veterinary Hygiene and Ecology, \\ University of Veterinary and Pharmaceutical Sciences Brno, Czech Republic
}

Received November 8, 2011

Accepted February 14, 2012

\begin{abstract}
The aim of the study was to determine mercury content in the muscle of indicator fish and to assess mercury pollution along the Bílina River, which is one of the most important tributaries of the Elbe River. A total of eight sites were chosen on the Bílina River for sampling. Indicator fish chub (Leuciscus cephalus L), roach (Rutilus rutilus L.) and brown trout (Salmo trutta m. fario L.) in the total numbers of 24, 26 and 27, respectively, were sampled at four locations, since at the remaining sites fish were absent. Mercury concentrations in the muscle of sampled indicator fish were measured using cold vapour atomic absorption spectrometry on an AMA 254 analyser. The highest mercury content $\left(0.12 \pm 0.027 \mathrm{mg} \cdot \mathrm{kg}^{-1}\right)$ was found in the muscle of roach at the Ústí nad Labem site and the lowest mercury content $\left(0.04 \pm 0.008 \mathrm{mg} \cdot \mathrm{kg}^{-1}\right)$ in the muscle of brown trout from the Brrezenec (the first upstream site) site. A significant difference $(P<0.05)$ between the analyzed fish species was found only between chub $\left(0.08 \mathrm{mg} \cdot \mathrm{kg}^{-1}\right)$ and brown trout $\left(0.04 \mathrm{mg} \cdot \mathrm{kg}^{-1}\right)$ at the Březenec site. The priority of this study was to assess the mercury contamination of the Bílina River because this river flows through a heavy industrial activity in the region (especially production of petrochemicals, agrochemicals, sorbents, plasticizers and textile auxiliaries). Despite the fact that the Bílina is an extensively polluted river, the obtained mercury results were very low and did not exceed the limit of $0.5 \mathrm{mg} \cdot \mathrm{kg}^{-1} \mathrm{set}$ by Commission Regulation No. 1881/2006.
\end{abstract}

Brown trout, roach, chub, river pollution

The aquatic environment is polluted by many different forms of industrial and agricultural waste. Waste water includes many chemicals, pharmaceuticals and metals. Most xenobiotic substances have the capacity to accumulate in living organisms and can be harmful to humans. One of them is mercury, a global pollutant with high toxicity even at very low concentrations. Its organic form, methylmercury, is easily taken up by biota and accumulates in the food chain, especially in fish.

In this study, the concentration of mercury was tested in fish from the Bílina River in the Czech Republic. The Bílina River springs on the slopes of the Ore Mountains in the Czech Republic, flows between the Czech Central Mountains and the Ore Mountains to the northeast, and joins the Elbe River at Ústí nad Labem. The catchment area of the river covers $1,071 \mathrm{~km}^{2}$. This river is extensively polluted due to heavy industrial activity in the region. Additionally, the largest open coal mine with the highest production of brown coal in the Czech Republic is located in this monitored area. In the past, a substantial portion of the flow was extracted for use in chemical plants in Záluží near Litvínov. The river flowed out as lifeless chemical waste water, heavily polluted with phenols and other chemicals. The situation much improved in the 1990s, when most of the industrial activity declined, especially the mining; however, the Bílina is still one of the most polluted rivers in the Czech Republic and contains high concentrations of inorganic and organic pollutants. The Bílina River basin is the location of large chemical plants, especially Unipetrol RPA, Litvínov-Záluží (a refinery and producer of petrochemical products, agrochemicals, sorbents, and composites), Enaspol Teplice (surfactants, plasticizers, textile auxiliaries), 
Spolchemie Ústí nad Labem (basic and special inorganic compounds, synthetic resins), and Česká Rafinérská, Litvínov-Záluží (petroleum products).

The aim of the study was to determine the mercury content in the muscle of indicator fish and to evaluate the concentration of mercury pollution along the flow of the Bílina River which could affect the Elbe River.

\section{Materials and Methods}

The study was done on the Bílina River in the Czech Republic at the following eight sites: Březenec (the first site upstream), Jirkov, Jiřetín, Litvínov-Záluží, Želenice, Bílina, Rtyně nad Bílinou, and Ústí nad Labem (Fig. 1). Study sites upstream were limited by natural (shallow riffles, boulder ramp) or artificial (weir) transversal barriers. The indicator fish species were chub (Leuciscus cephalus L.), roach (Rutilus rutilus L.) and brown trout (Salmo trutta m. fario L.) in the total numbers of 24, 26 and 27, respectively, collected from four localities on the Bílina River (Březenec, Jirkov, Jiřetín and Ústí nad Labem) by electrofishing in 2010; no fish were caught at the other four locations because of absence of fish in these parts of the river. The fish were weighed and their scales collected for age determination. The main characteristics of fish are summarized in Table 1.

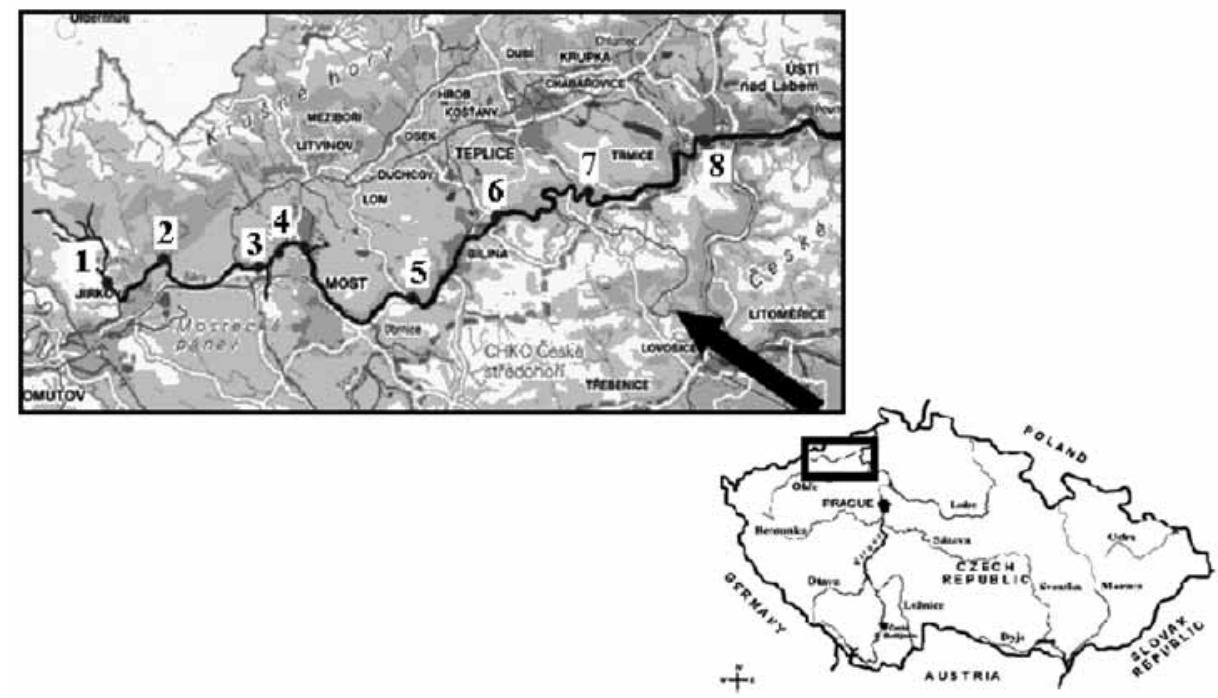

Fig. 1. Map of sampling sites on the Bílina River in the Czech Republic

Sampling sites: 1 - Březenec (the first upstream site) (river km 71), 2 - Jirkov (river km 68), 3 - Jiřetín (river km 58), 4 - Litvínov-Záluží (river km 54), 5 - Želenice (river km 42.5), 6 - Bílina (river km 34), 7 - Rtyně nad Bílinou (river km 16), and 8 - Ústí nad Labem (river km 0.2)

For mercury analysis, samples of muscle tissue were taken from the cranial parts of fish under the lateral line, and were placed into polyethylene bags, marked, and stored in a freezer at $-18{ }^{\circ} \mathrm{C}$. The amount of mercury in muscle was determined by cold vapour atomic absorption spectrometry on an AMA 254 analyser (Altec Ltd., Dvůr Králové n. L., Czech Republic). The accuracy of the method was confirmed using certified reference material BCR 464 (certified value $5.24 \pm 0.1 \mathrm{mg} \cdot \mathrm{kg}^{-1}$ ).

Statistical analyses were done using Statistica 8.0. for Windows software. Individual differences between the means were tested successively using the Kruskal-Wallis test at the level of the significance 0.05 .

\section{Results}

Mercury concentration was measured in the muscle of indicator fish. The contents of mercury in analyzed fish from individual sites are summarized in Figs 2-4. The highest 
Table 1. The main characteristics of indicator fish from the sampling sites of the Bílina River.

\begin{tabular}{llccr}
\hline Indicator fish & \multicolumn{1}{c}{ Site } & $\mathrm{n}$ & $\begin{array}{c}\text { Age } \\
(\mathrm{mean} \pm \mathrm{SD})\end{array}$ & $\begin{array}{r}\text { Body weight } \\
(\mathrm{mean} \pm \mathrm{SD})\end{array}$ \\
\hline Brown trout & Březenec & 17 & $2.5 \pm 0.51$ & $80 \pm 28.4$ \\
& Jirkov & 9 & $3.7 \pm 0.71$ & $231 \pm 154.8$ \\
& Jiř́tín & 0 & - & - \\
& Ústí nad Labem & 1 & $3.0 \pm 0.00$ & $148 \pm 0.0$ \\
Roach & Březenec & 2 & $3.0 \pm 0.00$ & $46 \pm 1.4$ \\
& Jirkov & 8 & $4.3 \pm 0.52$ & $158 \pm 59.7$ \\
& Jiř́tín & 9 & $3.0 \pm 0.00$ & $102 \pm 11.9$ \\
& Ústí nad Labem & 7 & $3.7 \pm 0.76$ & $391 \pm 225.1$ \\
Chub & Březenec & 6 & $4.2 \pm 1.17$ & $290 \pm 106.9$ \\
& Jirkov & 8 & $4.1 \pm 0.64$ & - \\
& Jiř́tín & 0 & $4.3 \pm 0.95$ & $325 \pm 160.3$ \\
\hline
\end{tabular}

average mercury content $\left(0.12 \pm 0.027 \mathrm{mg} \cdot \mathrm{kg}^{-1}\right)$ was found in the muscle of roach at the Ústí nad Labem site and the lowest $\left(0.04 \pm 0.008 \mathrm{mg} \cdot \mathrm{kg}^{-1}\right)$ in the muscle of brown trout from the Březenec site (the first site upstream).

Fish species were analysed separately and the following significant differences were found: in brown trout, a significantly higher $(P<0.05)$ mercury content was found at the Jirkov site in comparison with the Březenec site. For roach, a significantly lower $(P<0.05)$ mercury content was found at the Jiřetín site in comparison with the Ústí nad Labem site. Significant differences $(P>0.05)$ were not confirmed with respect to the mercury content in chub.

\section{Discussion}

This study was focused on mercury pollution along the stream of the Bílina River. Eight sites were chosen for fish sampling, but indicator fish were sampled only at four sites; no fish were found at the other four sites. Jurajda et al. (2010) performed a survey

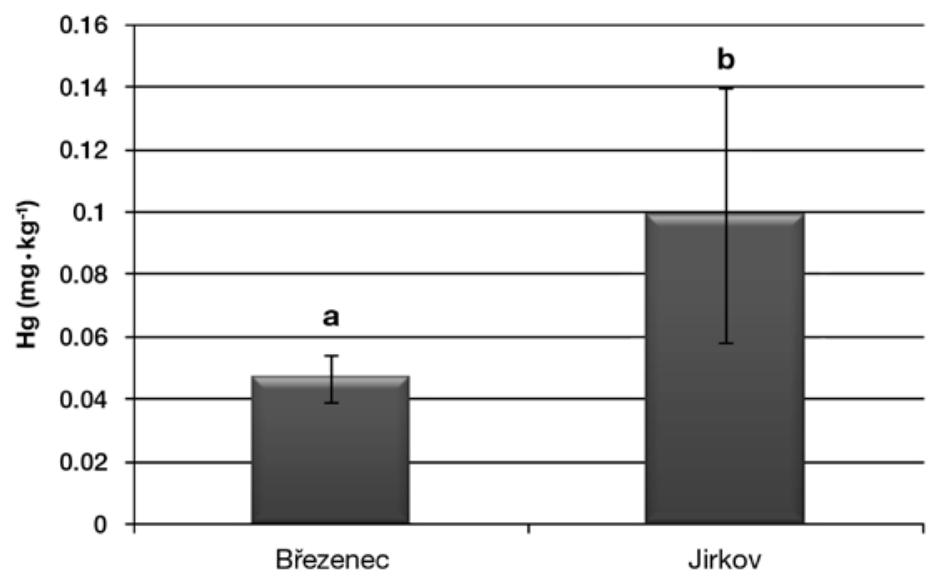

Fig. 2. Mercury content in the muscle of brown trout from the sampling sites of the Bílina River.

a,b different alphabetic letters differ significantly $(P<0.05)$ 


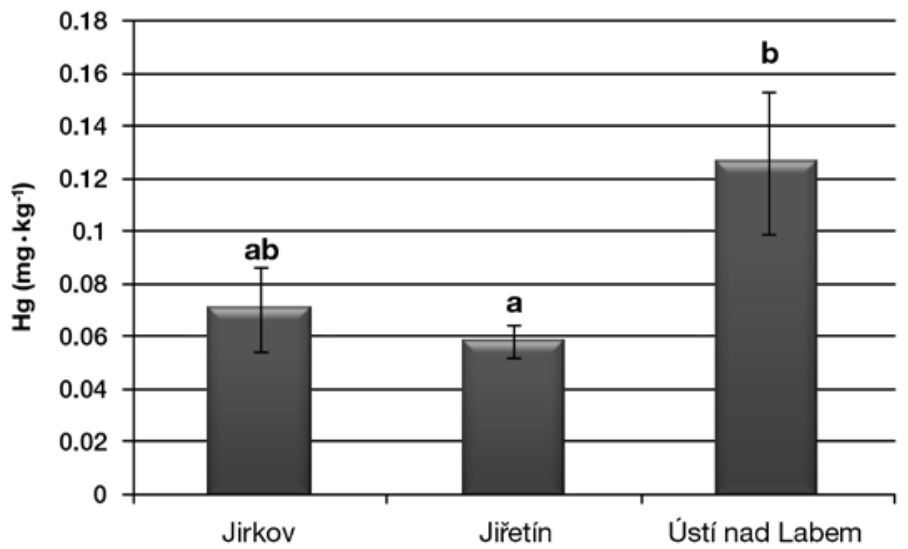

Fig. 3. Mercury content in the muscle of roach from the sampling sites of the Bílina River.

a,b different alphabetic letters differ significantly $(P<0.05)$

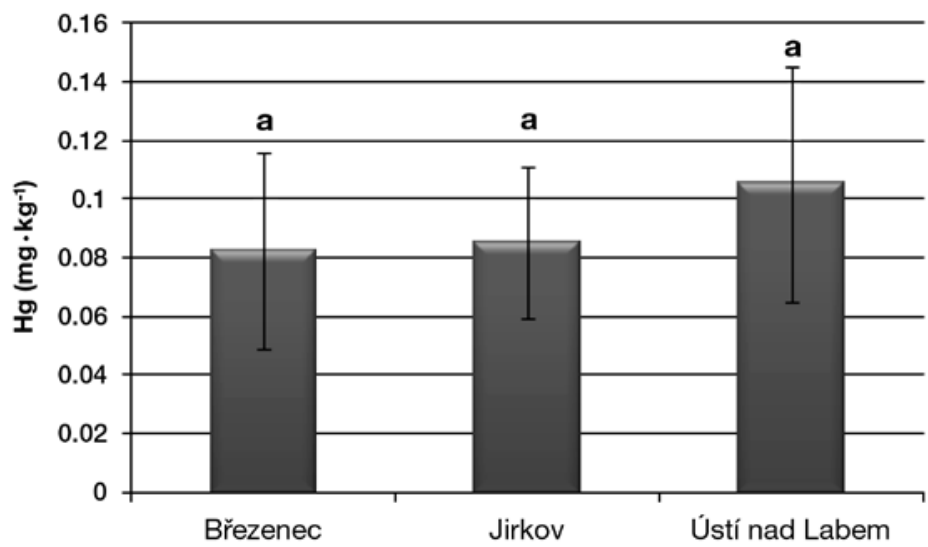

Fig. 4. Mercury content in the muscle of chub from the sampling sites of the Bílina River.

a,b different alphabetic letters differ significantly $(P<0.05)$

of fish and macroinvertebrates in the same river. They did not find fish at five sites from a total of 18 sites and only minimal occurrence of fish at the other sites. The river was very poor in species richness. The water in the river was heavily organically polluted and malodorous due to the outlets and waste water from the industry, and its conditions were not conducive to life. Adámek and Jurajda (2001) stated that in addition to waste outlets, the river is affected by the existence of extremely poor physical river habitat, which has also contributed to a sudden decline in macroinvertebrate and fish assemblage quality, or nearly absence of fish.

In our study, the lowest mercury content was found at the Březenec site (the first site upstream), except for roach. Mercury in the muscle of roach was lowest at the Jiřetín site, which was the site upstream of the city of Most. The highest values for roach and chub were found at Ústí nad Labem, which was the last site on the Bílina River monitored in this 
study and the last before its confluence with the Elbe River. Increased mercury value could be caused by the burden of waste water from Spolchemie Company in Ústí nad Labem which, however, eliminated mercury from the area of the chemical plant in late 1990s (Zlabek et al. 2005).

Although mercury concentrations were the highest at Ústí nad Labem in the muscle of roach and chub, they did not exceed the safety limit of $0.5 \mathrm{mg} \cdot \mathrm{kg}^{-1}$ in the muscle of fish and fish products set by Commission Regulation No. 1881/2006. Svobodová et al. (1993) studied fish from the Bílina River in a complex study focused on foreign compounds including mercury. They found a similar amount of mercury in the muscle of roach $\left(0.059 \pm 0.004 \mathrm{mg} \cdot \mathrm{kg}^{-1}\right)$ from the Jiřetín site. A slightly lower content than that found in our study $\left(0.021 \pm 0.0007 \mathrm{mg} \cdot \mathrm{kg}^{-1}\right)$ was found in the muscle of brown trout at the Březenec site. The mercury concentrations correspond with non-mercury polluted rivers in the Czech Republic. Analogous amount of mercury was found in chub from the Lužnice, Otava, Sázava, and Berounka Rivers $\left(0.07-0.13 \mathrm{mg} \cdot \mathrm{kg}^{-1}\right)$ and from the Svitava and Svratka rivers $\left(0.08-0.12 \mathrm{mg} \cdot \mathrm{kg}^{-1}\right)$ by Kružíková et al. (2008a, 2009). Kružíková et al. (2008b) studied tributaries of the Elbe River and investigated male chub from the Bílina River. Mercury concentrations in these fish were slightly higher (about $0.15 \mathrm{mg} \cdot \mathrm{kg}^{-1}$ ) than in our study. Water quality at the Ústí nad Labem site could be affected by the activities of the Spolchemie chemical company. This site is also located before the Bílina River's confluence with the Elbe, without natural or manmade transversal barriers; thus, fish from the Elbe River can occur here.

The Bílina River is suspected to be the most polluted river in the Czech Republic. There are several main sources of pollution: waste water from industry, municipal waste water, agricultural procedures, and mining activities (Kohušová et al. 2011). Because the Bílina River is an important tributary of the Elbe River, it affects the aquatic ecosystem of this river with respect to water quality and consequently remains a potential pollution risk to the North Sea (Stachel et al. 2003). Kohušová et al. (2011) indicated in a long-term study that the middle and lower portions of the Bílina River were heavily polluted by metals and organic pollutants. They identified the main sources of these contaminants to be oil, coal, the chemical industry, and municipal waste water. The Bílina River was also studied by Blahová et al. (2011), who detected polycyclic aromatic hydrocarbons (PAHs) using passive samples and 1-OHP in fish bile. Their study indicates that the highest level of PAH pollution is in the middle stretches of the river flow, especially at Litvínov-Záluží. This site is affected by waste water from the town of Litvínov and the refinery operated by Unipetrol RPA. The lowest PAHs were found at the Březenec site. In the case of 1-OHP, the highest value was determined at Ústí nad Labem and the lowest also at Březenec.

Despite the fact that the Bílina River is still one of the most polluted rivers in the Czech Republic and contains high concentrations of inorganic and organic pollutants, there are no known mercury sources upstream of Ústí nad Labem and in terms of mercury, it is polluted only to a very small degree.

\section{Acknowledgments}

This study was supported by the grant "Veterinary aspects of food safety and quality" MSM 6215712402 . The authors would like to thank colleagues from the Faculty of Fisheries and Protection of Waters (University of South Bohemia in České Budějovice) for fish sampling, and Matthew Nicholls for English revision.

\section{References}

Adámek Z, Jurajda P 2001: Stream habitat of water quality - chat influences stronger fish and macrozoobenthos biodiversity? Ecohydrol Hydrobiol 1: 305-311

Blahová J, Schandlová L, Grabic R, Fedorová G, Randák T, Svobodová Z 2011: Assessment of polycyclic aromatic hydrocarbon contamination of the Bílina River (Czech Republic) using passive water samplers and fish biliary metabolites. Acta Vet Brno 80: 353-357 
Commission Regulation (EC) No. 1881/2006 of 19 December 2006 setting maximum levels for certain contaminants of foodstuffs.

Jurajda P, Adámek Z, Janáč M, Valová Z 2010: Longitudinal patterns in fish and macrozoobenthos assemblages reflex degradation of water quality and physical habitat in the Bílina river basin. Czech J Anim Sci 55: 123-136

Kohušová K, Havel L, Vlasák P, Tonika J 2011: A long-term surfy of heavy metals and specific organic compounds in biofilms, sediments, and surface water in a heavily affected river in the Czech Republic. Environ Monit Assess 174: 555-572

Kružíková K, Randák T, Kenšová R, Kroupová H, Leontovyčová D, Svobodová Z 2008a: Mercury and methylmercury concentrations in muscle tissue of fis caught in major rivers of the Czech Republic. Acta Vet Brno 77: 637-643

Kružíková K, Svobodová Z, Valentová O, Randák T, Velíšek J 2008b: Mercury and methylmercury in muscle tissue of chub from the river Elbe main tributaries. Czech J Food Sci 26: 67-72

Kružíková K, Blahová J, Kenšová R, Jurčíková J, Hypr D, Svobodová Z 2009: Mercury and methylmercury content in chub from the Svitava and Svratka Rivers at agglomeration Brno. Czech J Food Sci 27: 470-476

Stachel B, Ehrhorn U, Heemken OP, Lepom P, Reincke H, Sawal G, Theobald N 2003: Xenoestrogens in the River Elbe and its tributaries. Environ Pollut 124: 497-507

Svobodová Z, Vykusová B, Máchová J, Piačka V, Bastl J, Hrbková M and Svobodník J 1993: Monitoring of foreign substances in fish from the Bílina River. (In Czech: Monitoring cizorodých látek v rybách z řeky Bíliny). Bulletin VÚRH Vodňany 29: 123-132

Žlábek V, Svobodová Z, Randák T, Valentová O. 2005: Mercury content in the muscle of fish from the Elbe River and its tributaries. Czech J Anim Sci 50: 528-534 